\title{
MENINGKATKAN PRESTASI BELAJAR MATEMATIKA PADA SUB BAHASAN PERKALIAN DENGAN MENGGUKAN MEDIA GAMBAR PADA SISWA KELAS III SDN 8 JURIT TAHUN PELAJARAN 2015/2016
}

\author{
Hilman \\ Pendidikan Guru Madrasah Ibtidaiyah, Intitut Agama Islam Hamzanwadi NW Pancor \\ Hilma4n69@gmail.com
}

\section{INFO ARTIKEL}

Riwayat Artikel:

Diterima:25-Januari-2021

Disetujui:31-Maret-2021

\section{Kata Kunci:}

Prestasi Belajar, Media gambar.

\section{ABSTRAK}

\begin{abstract}
Abstrak: Penelitian ini bertujuan untuk mengetahui efektifitas media gambar pada pelajaran matematika pada siswa kelas III SDN 8 Jurit. Jenis penelitian ini adalah penelitian tindakan kelas yang dilaksanakan 2 siklus secara bertahap yakni perencaraan, tindakan, observasi, evaluasi dan refleksi dengan menggukan lembar observasi aktifitas siswa dan lembar evaluasi hasil belajar siswa dalam empat kali pertemuan. Hasil penelitian ini menunjukkan prestasi belajar matematika pada sub bahasan perkalian pada siswa kelas III SDN 8 Jurit tahun 2015/2016 meningkat terlihat pada setiap pertemuan dan siklus. Pada pertemuan I siklus I ketuntasan siswa hanya mencapai $9.5 \%$ dengan nilai aktifitas siswa dengan skor 9 masih tergolong kurang aktif sedangkan pertemuan ke II siklus I terjadi peningkatan $52.96 \%$ dengan nilai aktifitas siswa 13 tergolong cukup aktif. Pada siklus II setalah diadakan perbaikan dalam pendekatan pembelajaran pertemuan I nilai ketuntasan siswa mencapai $59.37 \%$ dengan nilai aktifitas siswa dengan skor 17 tergolong cukup aktif kemudian I pertemuan ke II siklus II nilai ketuntasan siswa $90.62 \%$ dan nilai aktifitas siswadengan skor 22 tergolong sangat aktif. Dan penelitian dengan menggunakan media gambar pada sub bahasan perkalian dinyatakan berhasil dari standar ketuntasan klasikal yang sudal ditetapkan peneliti yakni $85 \%$ sehingga penelitian ini tdak dilanjutkan pada siklus beritkutnya.
\end{abstract}

\begin{abstract}
This study aims to determine the effectiveness of image media in mathematics lessons for third grade students of SDN 8 Jurit. This type of research is classroom action research which is carried out in 2 cycles in stages, namely planning, action, observation, evaluation and reflection using student activity observation sheets and student learning outcomes evaluation sheets in four meetings. The results of this study indicate that the learning achievement of mathematics in the multiplication sub-discussion in third grade students of SDN 8 Jurit in 2015/2016 increased seen in each meeting and cycle. At the first meeting of the first cycle, the student's completeness only reached $9.5 \%$ with the value of student activity with a score of 9 still classified as less active, while the second meeting of the first cycle there was an increase of 52.96\% with the activity score of 13 students being quite active. In the second cycle, after the improvement in the learning approach at the first meeting, the student's mastery value reached 59.37\% with a student activity score with a score of 17 being quite active, then at the second meeting in the second cycle, the student's completeness score was $90.62 \%$ and the student activity score with a score of 22 was classified as very active. And research using image media in the multiplication sub-discussion was declared successful from the classical completeness standard that had been set by the researcher, which was $85 \%$, so this research was not continued in the next cycle.
\end{abstract}

\section{A. LATAR BELAKANG}

Pada dasarnya pendidikan merupakan interaksi antara pendidik dengan peserta didik, untuk mencapai tujuan pendidikan, yang berlangsung dengan lingkungan tertentu (Sukmadinata, 2014). Dalam Undang-undang pendidikan No. 20 tahun 2003 adalah usaha sadar atau terencana untuk mewujudkan suasana belajar dan proses pembelajaran agar peserta didik secara aktif mengembangkan potensi dirinya untuk memiliki kekuatan

Spiritual keagamaan, pengendalian diri, kepribadian, kecerdasan, akhlak mulia serta keterampilan yang diperlukan dirinya, masyarakat, bangsa dan Negara. Para pelaksana sistem pendidikn di Indonesia harus berupaya mencapai tujuan pendidikan di atas. Dalam pasal 6 Undang-undang tersebut menyatakan bahwa, "Setiap warga negara berhak atas kesempatan yang seluas-luasnya untuk mengikuti pendidikan agar 
memperoleh pengetahuan, kemampuan dan keterampilan yang sekurang-kurangnya setara dengan pengtahuan, kemampuan dan keterampilan tamatan dasar" (Nasution, dkk. 1992).

Pendidikan juga memegang peranan yang sangat penting dalam kehidupan manusia. Karena dalam pendidikan manusia bisa berpikir dan memenuhi keingintahuan yang dimiliki manusia. Matematika ikut berkembang seirama dengan perkembangan zaman. Pola pikir matematika yang sering digunakan untuk perkembangan ilmu pengetahuan menjadikan matematika itu ilmu yang sangat penting, sehingga matematika diberikan dari sekolah dasar sampai perguruan tinggi. Sejauh ini pendidikan masih didominasi oleh pandangan bahwa pengetahuan dipandang sebagai perangkat fakta-fakta yang harus dihafal.

Sebagai ilmu dasar matematika seharusnya menjadi suatu pelajaran yang diminati dan disenangi oleh siswa. Namun kenyataannya bahwa rata-rata prestasi siswa pada mata pelajaran matematika selalu rendah. Hal tersebut dapat kita lihat pada hasil USB (Ujian Sekolah Bersama). Selain itu berdasarkan informasi yang diproleh dari guru bidang studi matematika yang mengajar dikelas III SDN 8 Jurit, nilai setiap ulangan harian adalah berkisar $37 \%$ - $45 \%$ dari jumlah siswa yang dapat mencapai nilai 65 keatas (Rohani, 2015).

Permasalahan di atas akhirnya berdampak pada rendahnya hasil belajar siswa. Hal tersebut dapat dilihat dari rata-rata hasil ulangan harian mata pelajaran matematika siswa kelas III SDN 8 Jurit yang cukup memperihatinkan. Untuk itu seorang guru harus jeli dalam memilih media yang digunakan dalam peroses pembelajaran berlangsung sehingga prestasi siswa akan lebih maksimal.

Berdasarkan uraian di atas dapat dilihat bahwa nilai siswa kelas III SDN 8 Jurit semester I pada materi pokok perkalian tahun lalu (2014) memiliki nilai dibawah rata-rata, sehingga peneliti menggunakan kelas III sebagai objek dalam penelitian. Menurut guru matematika kelas kelas III SDN 8 Jurit kurangnya motivasi, aktivitas siswa dalam pembelajaran matematika juga disebabkan kurangnya intraksi antara siswa dengan guru dan media yang digunakan tidak sesuai dengan karakter atau jiwa anak pada saat itu, intraksi siswa dengan siswa, kurangnya minat siswa terhadap mata pelajaran matematika yang konsep materi masih banyak yang abstrak sehingga siswa kurang dilatih untuk memecahkan masalah sendiri.

Dari permasalah yang telah diuraikan di atas maka upaya guru dalam menuntaskan masalah ini sangat diharapkan, yaitu dengan jalan membuat pelajaran yang menyenangkan, salah satunya dengan menggunakan media gambar dalam proses belajar mengajar. Media pempunyai arti yang cukup penting, karma dengan adanya penggunaan media gambar dalam kegiatan tersebut, ketidakjelasan bahan yang disampaikan dapat dibantu dengan media gambar tersebut sebagai perantara. Kerumitan bahan yang disampaikan kepada anak didik dapat disederhanakan dengan bantuan media. Media gambar dapat memiliki apa yang kurang mampu diucapkan melalui kata-kata atau kalimat tertentu, bahkan keabstrakan dapat dikongkritkan dengan kehadiran media. Dengan demikian anak didik dapat lebih mudah mencerna bahan dari pada tanpa bantuan media.

Media sebagai alat Bantu dalam proses belajar mengajar adalah suatu kenyataan yang tidak dapat dipungkiri. Karenamemang media gambar untuk membantu tugas guru dalam menyampaikan pesan-pesan dari bahan pelajaran yang diberikan oleh guru kepada anak didik. Guru sadar bahwa tanpa media maka bahan pelajaran sukar dipahami oleh setiap anak didik, terutama bahan pelajaran yang rumit atau kompleks. Media pelajaran dapat memberikan pengalaman kongkrit, motivasi belajar serta mempertinggi daya serap dan retensi belajar siswa (Sholatiah, 2010).

Dengan pendapat tersebut, jelas bahwa penggunaan media gambar mempunyai pengaruh besar terhadap prestasi belajar siswa. Media pembelajaran menempati posisi yang cukup penting sebagai komponen sistem pembelajran. Tanpa media, komunikasi tidak akan terjadi dan peroses pembelajaran sebagai proses komunikasi juga tidak akan bisaberlangsung secara optimal. Media pembelajaran adalah komponon integral dari sistem pembelajaran. Hal ini yang mendorong penulis melakukan penelitian untuk mengetahui apakah penggunaan media gambar dapat meningkatkan prestasi dan aktivitas belajar siswa mata pelajaran matematika kelas III SDN 8 Jurit.

\section{B. METODE PENELITIAN}

Jenis penelitian ini adalah penelitian tindakan kelas yang dilaksanakan dalam beberapa siklus. Penelitian tindakan kelas adalah penelitian yang dilakukan oleh guru didalam kelasnya melalui refleksi diri, dengan tujuan untuk memperbaiki kinerja sebagai guru, sehingga hasil belajar siswa menjadi meningkat. Perbaikan dilakukan secara bertahap dan terus-menerus selama kegiatan penelitian dilakukan. Oleh karena itu dalam PTK dikenal adanya siklus pelaksanaan berupa pola perencanaan, pelaksanaan tindakan, observasi, dan refleksi, pada siklus selanjutnya sampai tingkat yang diinginkan.

Prosedur atau langkah-langkah penelitian yang dilakukan terbagi dalam bentuk siklus kegiatan mengacu pada model Kemmis dan Taggart dimana setiap siklus terdiri dari empat kegiatan perencanaan tindakan, pelaksanaan, observasi, dan refleksi.

Tahap penelitian dilakukan sebagai berikut: 1) Refleksi awal pada tahap ini dilakukan identifikasi kesulitan siswa dalam menghadapi konsep dasar perkalian; 2) Perencanaan tindakan. Masalah yang ditemukan akan 
diatasi dengan melakukan langkah-langkah perencanaan tindakan yaitu menyusun instrumen penelitian berupa: Rencana Pelaksanaan Pembelajaran (RPP) dan lembar kegiatan siswa (LKS), soal tes, lembar observasi; 3) Pelaksanaan tindakan. Pada tahap ini dilakukan tindakan berupa: Pelaksanaan program pembelajaran, pengambilan atau pengumpulan data, hasil angket, lembar observasi, dan hasil tes; 4) Observasi, Refleksi, Evaluasi. Tahap ini dilakukan untuk mengumpulkan data-data dan menganalisisnya untuk kemudian dapat diambil kesimpulan dari penelitian ini.

Suharsimi (2000) mengatakan bahwa instrumen penelitian adalah alat bantu yang dipilih dan digunakan oleh peneliti dalam kegiatannya mengumpulkan data agar kegiatan tersebut jadi sitematis, dalam arti lebih cermat, lengkap, dan sistematis sehingga lebih mudah diolah. Instrumen penelitian yang digunakan adalah metode tes dan lembar observasi.

Untuk mendapatkan hasil yang maksimal, penelitian memerlukan teknik pengumpulan data yang tepat dan terorganisasi: 1) Sumber Data; 2) Jenis Data: Jenis data yang dikumpulkan adalah data kuantitatif dan kualitatif; 3) Cara Pengambilan Data: Cara pengambilan data dalam penelitian ini adalah: Data tentang situasi belajar mengajar didapat dari hasil observasi pada saat sedang pembelajaran berlangsung. Data hasil belajar diperoleh dengan cara memberikan tes evaluasi atau ulangan yang dilakukan pada akhir pertemuan. Data diolah atau disusun ulang dirumah.

Teknik Analisa Data:

1. Data Prestasi Belajar Siswa

Untuk mengetahui ketuntasan belajar siswa dianalisis dengan rumus:

a) Ketuntasan individu: Ketuntasan belajar individu dikatakan tuntas apabila siswa mencapai nilai $\geq 65$.

b) Ketuntasan belajar klasikal: Ketuntasan belajar secara klasikal dengan menggunakan rumus :

$$
K B=\frac{n_{1}}{n} \times 100 \%
$$

Keterangan:

$\mathrm{KB}=$ Ketuntasan Belajar

n 1 = Banyaknya siswa yang memperoleh $>65$

$\mathrm{n}$ = Banyaknya siswa

Sesuai dengan petunjuk teknik penilaian kelas dikatakan tuntas secara kalsikal terhadap prestasi pembelajaran yang disajikan apabila ketuntasan klasikal mencapai $85 \%$.

2. Data Aktivitas Siswa

Dari aktivitas belajar siswa selama pembelajaran dianalisis dengan cara menentukan skor yang diperoleh siswa, skor setiap individu tergantung banyaknya prilaku yang dilakukan siswa dari sejumlah indikator yang diamati. Setiap indikator prilaku siswa pada penelitian ini pemberian skornya mengikuti aturan berikut:

a) Skor 5 diberikan jika semua deskriptor nampak

b) Skor 4 diberikan jika 3 deskriptor nampak

c) Skor 3 diberikan jika 2 deskriptor nampak

d) Skor 2 diberikan jika 1 deskriptor nampak

e) Skor 1 diberikan jika tidak ada deskriptor nampak

Untuk mengetahui aktivitas siswa dalam pembelajaran, maka data hasil observasi yang berupa skor diolah dengan rumus:

$$
A=\frac{\sum x}{n . i}
$$

Keterangan:

A = Skor rata-rata aktivitas belajar siswa

$\sum \mathrm{x}=$ Jumlah skor aktivitas belajar seluruh siswa

$\mathrm{N}$ = Banyaknya siswa

$\mathrm{i} \quad=$ Banyak indikator

Skor maksimal ideal (SMI) merupakan skor tertinggi aktivitas siswa yang diperoleh apabila semua deskriptor yang diminati nampak yaitu skor 5. Untuk menilai katagori aktivitas siswa ditentukan terlebih dahulu MI dan SDI. 
Cara menentukan MI dan SDI adalah sebagai berikut:

$$
M I=\frac{\left(\mathrm{S}_{\max } I+S_{\min } I\right)}{2}=\frac{5+1}{2}=3 \quad \text { (Candiasa, 2010). }
$$$$
\operatorname{SDI} \stackrel{\left(\mathrm{S}_{\max } I-\mathrm{S}_{\min } I\right)}{=} \quad \stackrel{5-1}{6}=\frac{}{6}=0,67
$$

Keterangan:

MI = Mean Ideal

SDI $=$ Standar Deviasi Ideal

Tabel 1. Pedoman Skor Standar Aktivitas Belajar Siswa

\begin{tabular}{l|l|l}
\hline No & \multicolumn{1}{|c|}{ Interval } & \multicolumn{1}{c}{ Kategori } \\
\hline 1 & $\mathrm{X} \geq \mathrm{MI}+1,8$ SDI & Sangat Aktif \\
\hline 2 & MI +1.8 SDI $>\mathrm{X} \geq \mathrm{MI}+0,6$ SDI & Aktif \\
\hline 3 & MI $+0,6$ SDI $>\mathrm{X} \geq \mathrm{MI}-0,6$ SDI & Cukup Aktif \\
\hline 4 & MI $-0,6$ SDI $>\mathrm{X} \geq \mathrm{MI}-1,8$ SDI & Kurang Aktif \\
\hline 5 & $\mathrm{X}<\mathrm{MI}-1,8$ SDI & Sangat Kurang Aktif \\
\hline
\end{tabular}

Maka dapat diperoleh hasil sebagai berikut:

\begin{tabular}{l|l|l}
\hline No & \multicolumn{1}{|c|}{ Rentangan Skor } & \multicolumn{1}{c}{ Kualifikasi } \\
\hline 1 & $X \geq 4,20$ & Sangat aktif \\
\hline 2 & $4,20>X \geq 3,40$ & aktif \\
\hline 3 & $3,40>X \geq 2,59$ & Cukup aktif \\
\hline 4 & $2,59>X \geq 1,79$ & Kurang Aktif \\
\hline 5 & $X<1,79$ & Sangat Kurang Aktif \\
\hline
\end{tabular}

\section{Indikator Keberhasilan Penelitian}

Indikator peningkatan keberhasilan belajar berdasarkan Kurikulum Tingkat Satuan Pendidikan (KTSP) siswa kelas III SDN 8 Jurit sebagai berikut:

a. Secara individu, apabila siswa mampu mencapai standar Kriteria Ketuntasan Minimal yang telah ditetapkan dalam satuan pendidikan yang dalam hal ini untuk siswa kelas III SDN 8 Jurit. Kriteria Ketuntasan Minimal (KKM) untuk mata pelajaran matematika 65.

b. Secara klasikal, apabila $85 \%$ atau lebih dari siswa di kelas mencapai Kriteria Ketuntasan Minimal atau minimal $85 \%$ siswa mencapai nilai minimal $\geq 65$.

Indikator aktivitas siswa. Pelaksanaan tindakan akan dikatakan berhasil jika aktivitas siswa tergolong cukup aktif berdasarkan pedoman aktivitas siswa selama mengikuti pembelajaran.

\section{HASIL DAN PEMBAHASAN}

HASIL PENELITIAN

Penelitian ini dilakukan untuk meningkatkan prestasi belajar sisiwa pada sub pokok bahasan perkalian pada siswa kelas III SDN 8 Jurit Tahun Pelajaran 2015/2016. Adapun rincian pelaksanaan dan hasil penelitian ini dapat diuraikan dalam bagian-bagian berikut:

\section{Siklus I}

1. Perencaan: Perencaan yang dilakukan oleh guru (observer) adalan mengacu pada RPP (rencana pelaksaan pembelajaran). Adapun RPP siklus I terlampir.

2. Pelaksanaan: Pelaksanaan tindakan pada siklus I yaitu melaksanakan kegiatan belajar mengajar yang telah dilaksanakan dalam 2 kali pertemuan selama 4 jam pelajaran (1 kali pertemuan 2 jam pelajaran) yang dilanjutkan dengan evaluasi selama 45 menit. Pelaksanaan tindakan pembelajaran dilakukan berdasarkan skenario pembelajaran. Adapun pada awal kegiatan pembelajaran guru menyampaikan tujuan pembelajaran sehingga siswa mengetahui materi yang akan dibahas. Tujuan pembelajaran pada siklus I pertemuan 1 yaitu memberikan siswa tugas awal kemampuan siswa sebagai bahan pembanding dan mendeteksi tingkat kelemahan siswa. Sehingga guru (observer) mengetahui mana pelajaran yang paling ditekankan pada siswa untuk mendapatkan hasil yang lebih maksimal (prestasi meningkat) dengan alokasi waktu 1 jam pelajara 
(45 menit). Selanjutnya 1 jam pelajaran berikutnya (45 menit) membahas soal awal kemampuan tersebut sekaligus mejelaskan tata cara kerja perkalian dengan menggunakan media gambar.

Tabel 3. Data Prestasi Belajar Siswa Siklus I Pertemuan I

\begin{tabular}{l|l}
\hline Nilai tertinggi & 80 \\
\hline Nilai terendah & 10 \\
\hline Nilai rata-rata & 34.06 \\
\hline Jumlah seluruh siswa & 32 \\
\hline Jumlah siswa yang mengikuti tes & 31 \\
\hline Jumlah siswa yang tuntas & 3 \\
\hline Jumlah siswa tidak tuntas & 29 \\
\hline Prosentase ketuntasan & $9.37 \%$ \\
\hline
\end{tabular}

Sedangkan pada pertemuan 2 siswa dapat mempraktikan dan mempragakan cara kerja perkalian dengan menggunakan media gambar yang sudah disiapkan. Pada saat guru memberikan apersepsi yang terdiri dari, mengisi data kelas, berdoa, memotivasi siswa, mempersiapkan bahan dan media pembelajaran dan mengajukan pertanyaan pelajran minggu lalu. Siswa masih sedikit canggung ketika berintraksi dengan guru (observer), selanjutnya guru kembli menjelaskan bagaimana sistem kerja perkalian dengan menunjuk siswa langsung untuk mempraktikaannya di depan kelas dengan bimbingan guru dan dipilih siswa yang masih kurang aktif dalam mengkuti pembelajaran. Setelah itu guru memberikan tugas untuk dikerjakan sebagai bentuk evaluasi akhir tiap pembelajran selasai.

3. Data Prestasi Belajar Siswa: Setelah selesai proses pembelajaran sesuai dengan skenario yang telah direncanakan, pada siklus I akan dilakukan evaluasi, siswa diberi evaluasi dalam bentuk tes tertulis. Data lengkap tentang hasil evaluasi siswa dapat dilihat pada Lampiran 4 dan 8, tentang hasil evaluasi siklus I dapat dilihat pada table dibawah ini:

Tabel 4. Data Prestasi Belajar Siswa Siklus I Pertemuan II

\begin{tabular}{l|c}
\hline Nilai Tertinggi & 100 \\
\hline Nilai Terendah & 10 \\
\hline Nilai Rata-rata & 57.5 \\
\hline Jumlah seluruh siswa & 32 \\
\hline Jumlah siswa yang mengikuti tes & 28 \\
\hline Banyaknya siswa yang tuntas & 15 \\
\hline Banyaknya siswa yang tidak tuntas & 17 \\
\hline \multicolumn{1}{c|}{ Prosentase ketuntasan } & $46.87 \%$ \\
\hline
\end{tabular}

Dari tabel di atas dapat dijelaskan bahwa nilai rata-rata siswa adalah 57.5 tes evaluasi diikuti oleh 28 dar 32 siswa dan terdapat 15 siswa yang tuntas belajar dan 17 siswa yang tidak tuntas, sehingga ketuntasan belajar pada siklus I adalah 46,87 \% nilai ini kurang dari $85 \%$. Jadi kesempatannya bahwa pada pelaksanaan siklus I belum mencapai ketuntasan belajar yang diharapkan yaitu $85 \%$ siswa memperoleh nilai minimal pada saat evaluasi. Adapun pedoman dan hasil observasi belajar siswa dan kegiatan guru pada siklus I dapat dilihat pada tabel di bawah ini:

Tabel 5. Data Aktifitas Siswa Siklus I

\begin{tabular}{c|c|c|c|c|c}
\hline \multicolumn{2}{c|}{ Banyak siswa mengikuti tes } & \multicolumn{2}{c|}{ Jumlah skor } & \multicolumn{2}{c}{ Kategori } \\
\hline Pertemuan 1 & Pertemuan 2 & Pertemuan 1 & Pertemuan 2 & Pertemuan 1 & Pertemuan 2 \\
\hline 31 & 28 & 2.00 & 2.84 & Kurang aktif & Cukup Aktif \\
\hline
\end{tabular}

4. Observasi Proses Pembelajaran: Berdasarkan hasil observasi masih ada siswa yang belum mengerti dan yang tidak mau bertanya, dan tidak mau bekerja sama. Pada kegiatan pembelajaran ini guru pendamping mengisi lembar observasi untuk melihat kegiatan pembelajaran yang sedang berlangsung. Hasil observasi yang diperoleh adalah sebagai berikut: a) Kurangnya keberanian siswa untuk bertanya, mengemukakan pendapat, dan menjawab pertanyaan guru; b) Diskusi yang dilaksanakan belum efektif karena masih banyak siswa yang mengalami kesulitan dan bingung tanpa harus bertanya sama temannya; c) Kurangnya partisipasi siswa dalam menyimpulkan hasil belajar atau diskusi; d) Kurangnya pemahaman siswa dalam mengerjakan soal evaluasi yang diberikan.

5. Refleksi: Berdasarkan hasil yang diperoleh pada siklus I, baik hasil evaluasi dalam hal penguasaan materi maupun hasil observasi proses belajar mengajar, tujuan pembelajaran yang ditetapkan tidak tercapai. Dalam kontek ini maka refleksi dimaksudkan mengetahui kekurangan-kekurangan yang terjadi dan 
selanjutnya diadakan perbaikan maupun penyempurnaan dalam pelaksanaan siklus selanjutnya yaitu siklus II. Adapun hal-hal yang akan diperbaiki pada siklus II adalah sebagai berikut: a) Pada saat memberikan pertanyaan usahakan siswa menjawab dengan mengacungkan tangan terlebih dahulu; b) Guru harus membantu siswa yaitu dengan memberikan bimbingan dan melatih siswa agar dapat membuat kesimpulan dengan bahasannya sendiri; c) Antusias siswa dalam mengikuti kegiatan perlu ditingkatkan. Ini terlihat dari beberapa siswa yang belum siap mengikuti pelajaran; d) Respon siswa dalam pembelajaran masih rendah. Hal ini nampak dari keberanian siswa untuk bertanya, mengajukan pendapat dan mengajukan pertanyaan pada guru; e) Pada saat menutup kegiatan pembelajaran tidak bisa dilaksanakan seefisien mungkin karena banyaknya waktu yang tersita pada saat diskusi kelompok. Untuk itu peneliti harus menggunakan waktu seefisien mungkin pada siklus berikutnya; f) Membahas soal-soal evaluasi yang dianggap sulit.

\section{Siklus II}

1. Perencaan: Perencaan yang dilakukan oleh guru (obsever) adalah mengacau pada RPP (renaca pelaksaan pembelajaran) hasil refleksi siklus I. Adapun RPP siklus II terlampir.

2. Pelaksanaan: Pelaksanaan tindakan pada siklus II yaitu melaksanakan kegiatan belajar mengajar dilakukan dalam dua kali pertemuan selama 4 jam pelajaran kemudian dilanjutkan dengan evaluasi selama 60 menit, pelaksanaan tindakan pembelajaran dilakukan berdasarkan scenario pembelajaran. Adapun pada pada siklus II, awal kegiatan pembelajaran guru menyampaikan tujuan pembelajaran sehingga siswa mengetahui materi yang akan dibahas. Adapun langkah-langkanseelanjutnya sebagaimana pada siklus I.

3. Data Prestasi Belajar Siswa: Data lengkap tentang prestasi belajar siswa dan hasil observasi dapat dilihat pada lampiran 3 dan 4 . Adapun data ringkasan tentang hasil belajar siswa dapat dilihat pada tabel dibawah ini :

Tabel 6. Data Prestasi Belajar Siswa Siklus II pertmuan I

\begin{tabular}{l|c}
\hline Nilai Tertinggi & 100 \\
\hline Nilai Terendah & 10 \\
\hline Nilai Rata-rata & 62.18 \\
\hline Jumlah seluruh siswa & 32 \\
\hline Jumlah siswa yang mengikuti tes & 31 \\
\hline Banyaknya siswa yang tuntas & 19 \\
\hline Banyaknya siswa yang tidak tuntas & 13 \\
\hline Prosentase ketuntasan & $59.37 \%$ \\
\hline
\end{tabular}

Dari tabel di atas terlihat bahwa dari 32 orang siswa yang mengikuti tes evaluasi sebanyak 31 orang siswa dan terdapat 19 orang siswa yang tuntas belajar dengan rata-rata nilai 62,18 dan persentase ketuntasan mencapai 59,37\%. Hal ini menunjukkan bahwa pelaksanaan siklus II pertemuan I masih kurang dari nilai yang diharapkaan yaitu ketuntasan minimal $85 \%$ dari seluruh siswa. Adapun hasil tentang aktifitas siswa belajar siswa pada siklus II pertemuan I dapat dilihat pada tabel dibawah ini:

Tabel 7. Data Aktifitas Siswa Siklus II pertemuan I

\begin{tabular}{c|c|c|c}
\hline Banyak Siswa & Siswa yang ikut belajar & Jumlah Skor & Kategori \\
\hline 32 & 31 & 2.51 & Cukup Aktif \\
\hline
\end{tabular}

Berdasarkan data di atas pertemuan pertama pada siklus II menunjukkan bahwa nilai hasil belajar siswa dan perlu dievaluasi ulang pada pertemuan ke II. Adapun hasilnya adalah sebagai berikut

Tabel 8. Data Pretasi Belajar Siswa Siklus II pertemuan II

\begin{tabular}{l|c}
\hline Nilai Tertinggi & 100 \\
& 10 \\
& 67,03 \\
& 32 \\
& 29 \\
\hline Nilai Terendah & 20 \\
Nilai Rata-rata & \\
Jumlah siswa yang mengikuti tes & \\
Banyaknya siswa yang tuntas & \\
Banyaknya siswa yang tidak tuntas & 73.14 \\
\hline Nilai Rata-rata & \\
\hline
\end{tabular}




\begin{tabular}{l|c}
\hline Jumlah seluruh siswa & 32 \\
\hline Jumlah siswa yang mrngikuti tes & 32 \\
\hline Banyak siswa yang tuntas & 29 \\
\hline Banyak siswa yang tidak tuntas & 3 \\
\hline \multicolumn{1}{c|}{ Prosentase ketuntasan } & $90,62 \%$ \\
\hline
\end{tabular}

Adapun hasil tentang aktifitas belajar siswa pada siklus II pertemuan II dapat dilihat pada tabel dibawah ini:

Tabel 9. Data Aktifitas Siswa Siklus II pertemuan II

\begin{tabular}{c|c|c|c}
\hline Banyak Siswa & Siswa yang ikut belajar & Jumlah Skor & Kategori \\
\hline 32 & 32 & 3.78 & Aktif \\
\hline
\end{tabular}

4. Observasi proses Pembelajaran: Hasil observasi pada siklus II sudah dilakukan perbaikan-perbaikan berdasarkan hasil refleksi pada siklus sebelumnya dan kegiatan pembelajarannya sudah berjalan seperti yang diharapkan tetapi masih ditemukannya kekurangan pada sebagian siswa yaitu dalam pembelajaa masih ada yang tidak memperhatikan ketikan guru sedang menjelaskan dan dalam pemberian tugas kelompok masih sebagian yang ikut berpartisifasi dalam mengerjakan soal yang diberkan oleh guru.

5. Refleksi: Berdasarkan hasil yang diperoleh pada siklus II pertemuan ke II nilai ketuntasan belajar sebesar 90,62\% dengan rata-rata kelas III sebesar 73,14 adalah sudah mencapai syarat yang ditetepkan oleh peneliti. Namun melihat data diatas ada bebrapa siswa masih nilainya kurang dari standar yang ditentukan maka guru bidang study yang bersangkutan langkah-langkan atau cara mengatasinya. Adapun perbaikanperbaikan yang dilakukan pada siklus II antara lain: a) Guru meminta siswa untuk mengingat kembali pelajaran sebelumnya yang berkaitan dengan materi yang akan dibahas; b) Guru memotivasi siswa untuk berani bertanya dan mengajukan pertanyaan; c) Guru mengulas kembali beberapa konsep penting dari pelajaran sebelumnya yang belum dikuasai sepenuhnya oleh siswa; d) Guru memberikan penguatan atau penghargaan tehadap jawaban atau pertanyaan siswa dengan cara memberikan nilai tambah serta menanyakan kembali materi yang telah dibahas untuk menguji pemahaman siswa.

\section{PEMBAHASAN}

Berdasarkan analisis data, pemberian tindakan pada siklus I pertemuan I menunjukkan bahwa presentasi ketuntasan 9.37\% denga nilai rata-rata 34,06 hal ini menunujukkan bahwa nilai ketuntasan masih jauh dari nilai yang sudah ditentukan yaitu $85 \%$. Nilai awal ini adalah pemberian tugas langsung 45 menit pada jam pertama yang akan dijadikan sebagi penentuan nilai kemampuan awal siswa dan juga sebagai alat untuk mengetahui tingkat kesulitan siswa.

Adapun kesulitan disebabkan oleh beberapa faktor yaitu karena siswa langsung diberikan tugas tanpa harus belajar terlebih dahulu sehingga nilai siswa sangat rendah dari yang diperkirakan (guru) observer. Apalagi penerapan media gambar belum pernah diterapkan pada siswa tersebut khususnya pelajaran matematika sub bahasan perkalian kelas III. Selanjutnya pada 45 menit kedua digunakan untuk menjelaskan pengertian perkalian, sistem kerja kalian menggunakan media gambar yang sudah disiapkan, perkalian jejer, perkalian susun baik dengan tanpa menyimpan maupun dengan teknik menyimpan, baik yang berbentuk cerita yang melibatkan kehidupan sehari-hari maupun yang tidak.

Selama proses pembelajaran berlangsung guru melakukan observasi terhadap aktifitas siswa yang dicatat pada lembar observasi. Berdasarkan analisa data pada siklus I menunjukkan bahwa skor aktifitas siswa dalam mengikuti pembelajaran adalah sebesar 9 yang tergolong kurang aktif. Kemudian hasil observasi kegiatan guru menunjukkan bahwa kegiatan belajar mengajar dengan menggunaka media gambar cukup mengambail perhatian siswa.

Pada pelaksanaan siklus I pertemuan II banyak siswa yang rebut sendiri tanpa harus memperhatiakn penjelasan guru dan juga banyak yang asyik mencatat dan menggambar media yang sedang digunakan. Juga dalam pemberian tugas kelompok hanya satu atau dua orang saja yang kerja yang lainnya asyik bermain ditempat bangku kelompok masing-masing. Dalam diskusi kelompok berlangsung siswa hanya sebagian kecil yang berani mengacungkan tangannya untuk bertanya tentang kesulitan dalam tugas kelompok yang sedang dikerjakan. Sehingga pertemuan II siklus I memperolah hasil belajar dengan nilai rata-rata 57.5 dengan presentase ketuntasan $46.87 \%$. Hal ini menunjukkan bahwa presentse ketuntasan masih kurang dari yang sudah ditentukan yaitu 85\% dari seluruh siswa dan memperoleh data aktifitas siswa dengan skor 2.84 (cukup aktif). Untuk mengatasi kelemahan-kelemahan atau kekurangan pada siklus I maka guru melakukan perbaikan dalam pembelajaran pada siklus II agar siswa lebih aktif bertanya, mengerjakan tugas kelompok bersama dam 
memperhatikan dengan seksama adalah bentuk penyempurnaaan atau perbaikan pada siklus II. Dengan memberikan motivasi dan mengarahkan siswa agar berani melakukan hal-hal di atas.

Selama proses pembelajaran berlangsung pada siklus II pertemuan I juga diadakan observasi terhadap aktifitas siswa selama mengikuti proses pembelajaran. Berdasarkan analisis data hasil observasi menunjukkan bahwa skor rata-rata siswa dengan jumpah siswa yang tuntas 19 dan tidak tuntas 13 orang siswa. Ini menunjukkah bahwa presentase ketuntsasan siswa adalah 59,37\% masih juah dari standar yang sudah ditentukan. Adapaun nilai aktifitas siswa adalah 17 yang tegolong dengan kategori cukup aktif. Pada observasi pertemuan pertama masih jauh dari ketuntasan siswa yaitu siswa mendapat nilai 65 ketas harus mencapai 85\% sesuai dengan yang sudah ditentukan pada BAB III pada Indikator Ketuntasan Penelitin nomer 1 poin a. sehingga pebelajaran berlangsung pada pertemuan selanjutnya.

Pada pertemuan II siklus II dilakukan pembelajaran selama 45 menit dan dikuti dengan evaluasi akhir siklus dengan memperoleh hasil dengan nilai rata-rata siswa 73.14 dengan jumlah siswa yang tuntas sebanyak 29 orang siswa dan 3 orang siswa tidak tuntas dengan nilai minimum20 dan maksimum 100 dengan nilai aktivitas belajar siswa 3.78 adalah kategori aktif

Dari data siklus II pertemuan ke II menunjukkan bahwa ketuntasan belajar telah tercapai sesuai dengan yang diharapkan. Dalam proses pembelejaran yang diakukan selama dua siklus menunjukkan terjadinya peningkatan pretasi dan aktiitas belajar siswa. Adapun peningkatan ini dapat dilihat dari kenaikan hasil belajar siswa dan keaktifan siswa dari siklus I ke siklus II.

\section{SIMPULAN DAN SARAN}

Berdasarkan hasil penelitian dapat disimpulkan bahwa dengan pembelajaran matematika dengan media gambar dapat meningkatkat prestasi belajar siswa pada sub pokok bahasan perkalian hal ini dapat dilihat dari hasil belajar pada setiap siklus.

Dengan demikian penerapan media gambar dapat meningkatkan prestasi belajar matematika pada sub bahasan perkalian padan siswa kelas III SDN 8 Jurit tahun 2015/2016.

\section{DAFTAR RUJUKAN}

[1] Anitah, Sri. 2010. Media Pembelajaran, Kandipiro Surakarta: Yuma Pustaka, cet. II

[2] Atiturrahmainah. 2013. Pembelajaran Matematika I

[3] Candiasa, I. Made. 2010 Satatistik Univariat dan Bivariat Disertai Plikasi SPSS, Singaraja: UNDIKSA.

[4] Chulsum, Umi dan Novia, Windy. 2006. Kamus Besar Bahasa Indonesia, Surabaya: Kashiko Surabaya, cet. I.

[5] Daryanto. 2012. Media Pembelajaran, Bandung: PT. Sarana tutorial Nurani Sejahtera, cet. II

[6] Djamarah, Syaiful. Bahri. 2012. Prestasi Belajar dan Kopetensi Guru, Surabaya: Usaha Nasional

[7] Nastion, Noehi. 1992. Materi pokok Psikologi Pendidikan, Jakarta: Universitas Terbuka, cet. II

[8] Samsuri, Cung. Ali. 2003. Belajar Matematika Menyongsong Kurikulum Berbasis Kopetensi, Jilid 6B, Surabaya: Surabaya Intellectual Club, cet. II

[9] Sudjana, Nana dan Rivai, Ahmad. 2010. Media Pengajaran, Bandunag: Sinar Baru Algensido, cet. 8

[10] Sudjana, Nana. 2008. Penilaian Hasil Proses Belajar Mengajar, Bandung: PT Remaja Rosdakarya, cet. XI

[11] Sukmadianata, Nana. Syaodih. 2004. Landasan Psikologi Proses pendidikan, Bandung: PT Remaja Rosdakarya, cet. II 